\title{
Response of broiler turkeys to graded dietary levels of Palm Kernel Meal in replacement for maize
}

Ugwuene, M.C.

College of Animal Science and Animal Production, Michael Okpara University of Agriculture, Umudike, P.M.B. 7267, Umuahia, Abia State, Nigeria. E-mail address: chikmic58@yahoo.com

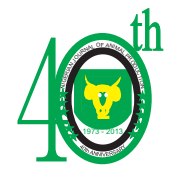

\begin{abstract}
The performance of local broiler turkeys fed dietary treatments in which palm kernel meal (PKM) replaced maize at 0,20, 40,60, 80 and 100 percent was evaluated. The replacement levels of $0,20,40$, 60, 80 and 100 percent represented diets 1, 2, 3, 4, 5 and 6 respectively. One hundred and eighty dayold unsexed turkey poults were allotted to the six dietary treatments. The treatments were replicated three times. Each replicate having ten poults. The experiment was carried out as a completely randomized design experiment. The feeding trial lasted for 24 weeks. With the exception of mortality, significant differences $(P<0.05)$ existed in the final weight, feed intake, weight gain and feed conversion ratio. The final weight and weight gain of birds fed diet 4 (60\% replacement level) were not significantly different $(P>0.05)$ from that of diet $3(40 \%$ replacement level) but were significantly higher $(P<0.05)$ than other dietary treatments. Feed intake and feed conversion ratio increased as the level of replacement increased. There were no significant differences $(P>0.05)$ in the feed conversion ratio of turkeys fed diets 1, 2, 3, and 4. There were no significant differences $(P>0.05)$ in slaughter weight, dressed weight, breast, wings and back cuts of turkeys fed the various dietary treatments. Dressing percentage values were similar for birds fed diets 1, 2, 3, and 5. Abdominal fat of turkeys increased with increasing concentration of PKM at the expense of maize in the diets. The thigh weight of turkeys fed diets 1, 2, 3 and 6 were not significantly different $(P>0.05)$ but were significantly higher than that of diets 4 and 5; whereas the drumstick weight of birds fed diets 2 to 6 were significantly higher than that of diet 1. Similarly meat-to-bone ratio of turkeys fed diet 3-6 were significantly higher $(P<0.05)$ than that of diets 1 and 2. The spleen of turkeys fed diets 2 was higher than others. Palm kernel meal can replace maize up to 60 percent in the diet of local broiler turkeys for good growth and carcass performance.
\end{abstract}

Keywords: Broiler Turkeys, Performance Palm Kernel Meal and maize

\section{Introduction}

There is a stiff competition between man and livestock for maize as industrial raw material and food/feedstuff. This competition arose as a result of the low production level of maize in Nigeria leading to inadequate supply and resulting in high cost of livestock feed which in turn reduces the expected profit of farmers (Durunna et al., 2000). Although maize constitutes about 50 percent of the proportion of ingredients used in formulating poultry rations in Nigeria due to its high energy content and easily hydrolysable carbohydrate, its high cost calls for its replacement or substitution in the diet of livestock animals.

The high price of maize has led to search for alternatives. There has been an increase in the awareness of usage of agro-industrial by-products as replacements for grains especially maize in livestock rations (Ukachukwu et al., 2003). Agro-industrial by-products such as palm kernel meal, rice husk, cocoa pod husk etc are cheap and abundantly available in Nigeria and so can serve as alternatives for conventional feed ingredients such as maize in the formulation of poultry rations. Palm kernel meal which is a by-product of Palm kernel oil extraction was said to be palatable and satisfactory when used in poultry nutrition. 
The economic advantages arising from the low cost of Palm kernel meal relative to cereals together with its ever-increasing global production (Ataga, 1984), as well as its considerable potential as a good source of both dietary protein and energy (Olomu, 1995 ) would seem to justify the increasing use of palm kernel meal in animal feeding. The world wide production of palm kernel in 2009 was about 2.66 million tones (FAO, 2010). Palm kernels yield between 46 and 52 percent oil and 54 and 48 percent palm kernel meal depending on the variety of palm kernel and method of extraction (Godin and Spensley, 1972).

The use of palm kernel meal in poultry nutrition dated many decades ago when Temperton and Dudley (1940) reported that birds fed palm kernel meal recorded satisfactory egg production. Though palm kernel meal has some inherent drawback such as its grittiness and fibrous nature (Oyenuga, 1968), it would still be used as supplement up to 20 percent in broiler chicken, 25 percent in swine and 34 percent in starter pullet diets without adverse effect in the performance of the animals (Yeong, 1980; Hutagalung, 1980; Onwudike, 1986b).

Palm kernel meal could serve as replacement for maize in poultry diets having a crude protein content of 19-21 percent and metabolisable energy value of 2600-2790keal $/ \mathrm{kg}$ feed (Nwokolo et al., 1997; Fetuga et al., 1973; Onwudike, 1986a).

There is no competition between man and livestock for palm kernel meal presently in Nigeria. Palm kernel meal is cheap and readily available. Its grittiness and fibrous nature may be ameliorated by the high residual oil content, depending on the method of extraction of oil (Jegede et al., 1994; Olomu, 1995).

Turkey production in Nigeria has hitherto remained largely at the subsistence level. Increase turkey production in Nigeria must therefore be seriously encouraged taking advantage of the bird's large size, fast growth rate, high fecundity and excellent meat quality, in order to solve the problem of low protein intake in the nation. There is however, a lack of information on the replacement value of palm kernel for maize in the diet of Nigerian local turkeys hence the necessity of this study.

\section{Materials and Methods \\ Location and Duration of the Experiment}

This study was conducted at the poultry unit of the Michael Okpara University of Agriculture Teaching and Research Farm, Umudike in Abia State of Nigeria. Umudike lies in the co-ordinates of $5^{\circ}$ north and $7^{\circ}$ east and located within the tropical rain forest zone of South Eastern Nigeria. The experiment lasted for 24 weeks during which turkey starter, grower and finisher rations were fed the birds ad libitum.

\section{Experimental Diets and Design}

Six dietary treatments in which palm kernel meal replaced maize at $0,20,40,60,80$, and 100 percent were formulated (table 1 ) with the principles of weight-to-weight replacement as contained in the procedures of (Tewe, et al., 1982; Onwudike, 1986b; Esonu and Udedibie, 1993). The proximate composition of the test ingredients procured from Umuahia market was determined before ration formulation. Proximate analysis of the test diets was also carried out. The design of the study was a Completely Randomized Design with each of the six dietary treatments replicated three times.

Experimental Animals and Management A total of 180 turkey poults procured from a reputable hatchery at Owerri, Imo State of Nigeria were randomly allotted to the six 


\section{Table 1: Percentage Composition of Treatment Diets}

\begin{tabular}{lllllllllllllllllll}
\hline & \multicolumn{9}{c}{ Starter Rations } & \multicolumn{4}{c}{ Grower Rations } & \multicolumn{5}{c}{ Finisher Rations } \\
\hline Ingredients & 1 & 2 & 3 & 4 & 5 & 6 & 1 & 2 & 3 & 4 & 5 & 6 & 1 & 2 & 3 & 4 & 5 \\
\hline Maize & 40 & 32 & 24 & 16 & 8 & 0 & 58 & 46.4 & 34.8 & 23.2 & 11.6 & 0 & 68 & 54.4 & 40.8 & 27.2 & 13.6 & 0 \\
Palm kernel meal & 0 & 8 & 16 & 24 & 32 & 40 & 0 & 11.6 & 23.2 & 34.8 & 46.4 & 58 & 0 & 13.6 & 27.2 & 40.8 & 54.4 & 68 \\
Soyabean meal & 51 & 51 & 51 & 51 & 51 & 51 & 33 & 33 & 33 & 33 & 33 & 33 & 24.5 & 24.5 & 24.5 & 24.5 & 24.5 & 24.5 \\
Fish meal & 5.5 & 5.5 & 5.5 & 5.5 & 5.5 & 5.5 & 5.5 & 5.5 & 5.5 & 5.5 & 5.5 & 5.5 & 4 & 4 & 4 & 4 & 4 & 4 \\
Bone meal & 3 & 3 & 3 & 3 & 3 & 3 & 3 & 3 & 3 & 3 & 3 & 3 & 3 & 3 & 3 & 3 & 3 & 3 \\
Salt & 0.25 & 0.25 & 0.25 & 0.25 & 0.25 & 0.25 & 0.25 & 0.25 & 0.25 & 0.25 & 0.25 & 0.25 & 0.25 & 0.25 & 0.25 & 0.25 & 0.25 & 0.25 \\
Vit/Min. Premix & 0.25 & 0.25 & 0.25 & 0.25 & 0.25 & 0.25 & 0.25 & 0.25 & 0.25 & 0.25 & 0.25 & 0.25 & 0.25 & 0.25 & 0.25 & 0.25 & 0.25 & 0.25 \\
\hline Total & 100 & 100 & 100 & 100 & 100 & 100 & 100 & 100 & 100 & 100 & 100 & 100 & 100 & 100 & 100 & 100 & 100 & 100 \\
Cal C. P. (\%) & 28.59 & 29.3 & 30.19 & 30.99 & 31.79 & 32.59 & 22.63 & 23.87 & 24.97 & 26.12 & 27.28 & 28.45 & 19.01 & 20.36 & 21.72 & 23.08 & 24.40 & 25.81 \\
Cal. M.E. (Kcal/kg) & 2891 & 2827 & 2763 & 2699 & 2635 & 2571 & 3019 & 2924 & 2831 & 2738 & 2645 & 2553 & 30.85 & 2976 & 2868 & 2759 & 2650 & 2541 \\
\hline
\end{tabular}


dietary treatments resulting in 30 poults per treatment and 10 per replicate. The birds were reared on deep litter. A recommended vaccination and medication schedule for turkey production was strictly implemented. New castle disease vaccines (NDV) such as NDV intraocular, NDV lasota and NDV komorov were administered at $1^{\text {st }}$ day, 3 weeks and 12 weeks of age respectively whereas vaccination against fowl pox disease was done at $8^{\text {th }}$ week (Eruvbetine et al., 1996). Coccidiostat, antibiotics and vitamin drugs were administered to the birds when necessary (Bains, 1979).

\section{Data Collection and Analysis}

Data were collected on feed intake, weight changes, feed conversion ratio (FCR) and mortality of the birds. At the end of the experiment, one bird whose weight was closest to the mean live weight was selected from each of the three replicates of the six treatments. The eighteen birds were starved of feed for 12 hours and thereafter slaughtered by severing their jugular veins with sharp knife. The slaughtered birds were scalded in hot water, defeathered and eviscerated. This enabled data on carcass yield and organ proportions to be determined.

The data collected were subjected to analysis of variance (ANOVA) according to the procedure of Steel and Torrie (1980). Significant means were separated using Duncan's new multiple range test (Duncan, 1955).

\section{Results and Discussion}

With the exception of initial weight and mortality, significant differences existed among the values of the other growth parameters (table 2).

Feed intake and feed conversion ratio increased with level of experiment. Final weight and weight gain of turkeys fed dietary treatments increased as the levels of replacement increased up to 60 percent replacement and decreased thereafter.

The range of final weight of birds fed the dietary treatments (4167.67-5229.33g) was higher than that reported by Ojewola et al., (2001) for local turkey. However, the final weight reported by Leeson and Summers (1980) for large white turkeys was higher than what obtained here probably because large white turkeys are heavy breeds. The final weight of turkeys fed diet $4(60 \%$ replacement) was higher than others because the weight gain of birds fed diet 4 was higher than others too. This is in agreement with the report of Obioha (1992) that weight gain determines the outcome of the final weight.

The increase in feed intake with level of replacement was due to the decrease in dietary energy with increasing level of replacement of PKM for maize. Birds fed lower dietary energy content eat more to satisfy their energy needs (Olomu, 1995; Ojewola, et al., 2003). This theory seemed to have influenced the feed intake of the birds more than the fact that palm kernel meal is gritty, fibrous and less palatable (Oyenuga, 1968; Onwudike, 1986a; Olomu, 1995). The increase in feed intake was also to support the increase in weight gain with level of replacement since increase in cell multiplication (growth) demands higher dietary energy and protein which are derivable from higher feed intake (Frandson, 1981; McDonald et al., 1995). The feed intake of birds fed diets 5 and 6 were significantly higher $(\mathrm{P}<0.05)$ than others.

The weight gain of birds fed diets 3 and 4 were not significantly different $(\mathrm{P}>0.05)$ from each other but that of birds fed diets 4 (60\% replacement) was higher than others. The weight gain of birds feed diets 2 to 6 were higher than that of diet $1 \quad(0 \%$ 
Ugwuene

Table 2: Growth Performance, Carcass Yield and Organ Proportion of Turkeys fed the Treatment Diets.

\begin{tabular}{|c|c|c|c|c|c|c|c|}
\hline \multicolumn{8}{|c|}{ Treatment Diets } \\
\hline Parameters & 1 & 2 & 3 & 4 & 5 & 6 & SEM \\
\hline \multicolumn{8}{|l|}{ Growth performance } \\
\hline Initial weight/bird(g) & 51.00 & 51.33 & 50.67 & 51.00 & 51.00 & 50.67 & 0.48 \\
\hline Final weight/birds(g) & $4167.67^{\mathrm{c}}$ & $4473.00^{\mathrm{bc}}$ & $4767.00^{\mathrm{ab}}$ & $5229.33^{\mathrm{a}}$ & $4187.67^{\mathrm{c}}$ & $4175.67^{\mathrm{c}}$ & 166.31 \\
\hline Feed intake/bird/day (g) & $93.62^{\mathrm{d}}$ & $107.45^{\mathrm{d}}$ & $122.10^{\mathrm{cd}}$ & $143.04^{\mathrm{bc}}$ & $156.91^{\mathrm{ab}}$ & $174.12^{\mathrm{a}}$ & 15.64 \\
\hline Weight gain/bird/day(g) & $24.50^{\mathrm{c}}$ & $26.32^{\mathrm{bc}}$ & $28.07^{\mathrm{ab}}$ & $30.82^{\mathrm{a}}$ & $24.62^{\mathrm{bc}}$ & $24.60^{\mathrm{bc}}$ & 0.86 \\
\hline Feed conv. Ratio (feed/gain) & $3.82^{\mathrm{b}}$ & $4.08^{\mathrm{b}}$ & $4.35^{\mathrm{b}}$ & $4.64^{\mathrm{b}}$ & $6.37^{\mathrm{a}}$ & $7.09^{\mathrm{a}}$ & 0.25 \\
\hline \%mortality (AV. Weekly) & 0.19 & 0.19 & 0.16 & 0.16 & 0.20 & 0.19 & 0.05 \\
\hline \multicolumn{8}{|l|}{ Carcass Yield } \\
\hline Slaughter weight/bird(g) & 4161.53 & 4361.76 & 4546.42 & 5068.18 & 3987.50 & 4008.23 & 822.18 \\
\hline Dressed weight/bird(g) & 2915.30 & 2988.79 & 3157.28 & 3219.87 & 2749.38 & 2711.57 & 533.69 \\
\hline$\%$ dressed weight/bird & $70.21^{\mathrm{a}}$ & $68.83^{\mathrm{ab}}$ & $69.58^{\mathrm{ab}}$ & $63.65^{\mathrm{c}}$ & $68.95^{\mathrm{ab}}$ & $67.65^{\mathrm{b}}$ & 0.51 \\
\hline$\%$ abdominal fat $/ \mathrm{bird}$ & $1.00^{\mathrm{c}}$ & $1.07^{\mathrm{c}}$ & $1.25^{\mathrm{b}}$ & $1.47^{\mathrm{a}}$ & $1.50^{\mathrm{a}}$ & $1.60^{\mathrm{a}}$ & 0.039 \\
\hline Breast (\%) & 31.64 & 29.68 & 31.13 & 31.27 & 30.71 & 29.70 & 0.56 \\
\hline Thigh (\%) & $17.60^{\mathrm{a}}$ & $18.85^{\mathrm{a}}$ & $17.36^{\mathrm{a}}$ & $14.98^{\mathrm{b}}$ & $15.50^{\mathrm{b}}$ & $18.47^{\mathrm{a}}$ & 0.39 \\
\hline Drumstick (\%) & $12.01^{\mathrm{b}}$ & $14.97^{\mathrm{a}}$ & $15.32^{\mathrm{a}}$ & $15.05^{\mathrm{a}}$ & $15.30^{\mathrm{a}}$ & $14.19^{\mathrm{a}}$ & 0.31 \\
\hline Wings $(\%)$ & 15.86 & 13.92 & 13.98 & 14.91 & 15.10 & 13.20 & 0.63 \\
\hline Back $(\%)$ & 22.56 & 22.36 & 21.87 & 23.17 & 23.08 & 23.43 & 0.43 \\
\hline Meat (\%) & $72.04^{\mathrm{c}}$ & $73.23^{\mathrm{bc}}$ & $74.49^{\mathrm{ab}}$ & $74.00^{\mathrm{abc}}$ & $75.33^{\mathrm{ab}}$ & $75.76^{\mathrm{a}}$ & 0.54 \\
\hline Bone $(\%)$ & $26.78^{\mathrm{a}}$ & $26.20^{\mathrm{ab}}$ & $25.21^{\mathrm{abc}}$ & $25.00^{\mathrm{bc}}$ & $24.13^{\mathrm{c}}$ & $24.28^{\mathrm{c}}$ & 0.43 \\
\hline Meat: Bone Ratio & $2.69^{\mathrm{c}}$ & $2.80^{\mathrm{c}}$ & $2.95^{\mathrm{ab}}$ & $2.96^{\mathrm{ab}}$ & $3.12^{\mathrm{a}}$ & $3.13^{\mathrm{a}}$ & 0.055 \\
\hline \multicolumn{8}{|l|}{ Organ Proportion } \\
\hline Total visceral (\%) & 9.94 & 10.88 & 10.07 & 8.92 & 10.42 & 11.27 & 1.76 \\
\hline Kidney $(\%)$ & 0.82 & 1.15 & 0.65 & 0.91 & 0.73 & 0.78 & 0.15 \\
\hline Liver (\%) & 2.01 & 2.08 & 2.04 & 1.17 & 2.09 & 2.26 & 0.39 \\
\hline Gizzard + Proventriculus (\%) & 2.92 & 2.83 & 3.75 & 2.83 & 3.01 & 2.89 & 0.46 \\
\hline Heart $(\%)$ & 0.70 & 1.16 & 0.99 & 0.92 & 1.06 & 1.16 & 0.19 \\
\hline Spleen $(\%)$ & $0.40^{\mathrm{ab}}$ & $0.76^{\mathrm{a}}$ & $0.58^{\mathrm{ab}}$ & $0.29^{\mathrm{b}}$ & $0.69^{\mathrm{ab}}$ & $0.68^{\mathrm{ab}}$ & 0.10 \\
\hline Small and large Intestine $(\%)$ & 3.07 & 2.89 & 2.05 & 2.78 & 2.82 & 3.48 & 0.50 \\
\hline
\end{tabular}

replacement). The higher dietary fat content of diets 2 to 6 may have contributed to the higher weight gain of birds fed 2 to 6 than that of diet 1 since fat supply about twice the energy derivable from carbohydrates (Gurr and Harwood, 1991). The extra energy supplied by higher fat content of diets 2 to 6 may have been stored in form of fat in the adipose tissues of the birds (McDonald et al., 1995) which may have contributed to the higher weight gain of turkeys fed diets 2 to 6 . This result was similar to the report of Ojewola et al., (2001) and Ugwuene et al (2005).

The range of weight gain (24.50$30.82 \mathrm{~g} /$ bird) obtained in this study fell within the weight gain reported for tropical turkeys (Aduku, 1993). The weight gain obtained in this study was however, lower than that $(48.55-54.76 \mathrm{~g} / \mathrm{bird})$ reported by (Sell et al., 1985; Summers et al 1985; Summers and Spratt, 1990) for exotic breeds of turkeys.

The increase in feed conversion ratio with increasing concentration of PKM in the diet was due to increase in fibre content of the dietary treatments as the level of replacement increased. This implied that the efficiency of conversion of feed to weight decrease as the level of replacement increased. Higher dietary fibre depresses feed digestibility (Gupta et al., 1973; Felix et al., 1990; McDonald et al., 1995; Dung et al., 2002) because birds do not possess the right enzymes to hydrolyze fibrous feeding materials (McDonald et al., 1995; Olomu, 
1995). The FCR of birds fed diet1 (0\% replacement) was the least implying higher feed efficiency probably because the carbohydrate of maize is very hydrolysable (Olomu, 1995). With regards to final weight, weight gain and FCR, it could be said that palm kernel meal can replace maize up to 60 percent for good performance of turkeys.

Among the carcass yield parameters, there were no significant differences $(\mathrm{P}>0.05)$ in the values of slaughter weight, dressed weight, breast, wings and back cut-parts of turkeys fed the treatment diets. However, significant differences $(\mathrm{P}<0.05)$ existed in the percent dressed weight, abdominal fat, thigh and drumstick. Others are percentage meat, bone and meat: bone ratio. Abdominal fat and meat: bone ratio increased with increase in level of replacement. The slaughter weight and dressed weight increased with level of replacement up to 60 percent replacement and declined thereafter. The values obtained for percentage dressed weight, breast, thigh, drumstick, wings and back cut-parts were however, inconsistent with the level of replacement of PKM for maize. The numerical values of percentage dressed weight, breast and wings of turkeys fed diet 1 ( $0 \%$ replacement) were higher than others. The trend in the values of percentage meat was irregular with the level of replacement of PKM for meat. Whereas percentage meat increased with level of replacement up to 40 percent, it decreased at 60 percent and increased thereafter from 80 to 100 percent replacement. The percentage bone however decreased with level of replacement up to 80 percent. The numerical value of dressed weight of turkeys fed diet 4 (60\% replacement) was higher than others.

The percentage dressed weight of turkeys fed diets 1,2,3 and 5 were not significantly different $(\mathrm{P}>0.05)$ from one another but were higher than others. The numerical value of percentage dressed weight of turkeys fed diet1 was however, higher than others. This result was similar to the report of Ojewola et al., (2003) and Sell et al., (1985) that higher dietary energy gave higher percentage dressed weight.

The percentage abdominal fat of turkeys fed diets 4,5 and 6 were not significantly different $(\mathrm{P}>0.05)$ from one another but were higher than that of diets 1,2 , and 3 . The increase in abdominal fat of turkeys with increase in level of replacement was probably due to increase in dietary fat as the level of replacement increased and so excess fat was stored in the abdomen (McDonald et al., 1995; Olomu, 1993). This result was so irrespective of the decreasing dietary energy with increase in level of replacement as a result of decreasing proportion of maize in the diet. The trend in the values of breast, thigh, drumstick, wings and back was inconsistent with the level of replacement of PKM for maize. There was no significant difference $(\mathrm{P}>0.05)$ in the thigh of turkeys fed diets 1 , 2, 3 and 6 whereas the drumstick of turkey fed diets 2 to 6 were significantly higher $(\mathrm{P}<0.05)$ than that of turkeys fed diets $1(0 \%$ replacement).

Replacement of maize with PKM up to 100 percent resulted in good performance in terms of breast, drumstick, wings and back regions. Breast meat of turkeys contains the highest protein value among other parts (Summers et al., 1985) and breast yield accounts for about 30 percent of the cut parts of a turkey (Ferket and Sell, 1989; Summers and Spratt, 1990).

The percentage meat and meat: bone ratio of turkeys fed diets 3, 4, 5 and 6 were significantly higher $(\mathrm{P}<0.05)$ than that of turkeys fed diets 1 and 2 . The higher dietary protein content of diets 2 to 6 may have 
influenced this result. This agrees with the reports that increase in dietary protein enhanced greater meat formation (Sell et al., 1985; Summers et al., 1985; Ojewola et al., 2001). High quality carcass is in most cases regarded as one with a large amount of muscle (meat) and small amount of bone (Summers et al., 1985; Sell et al., 1989; Ojewola et al., 2001).

With the exception of spleen, there was no significant difference $(\mathrm{P}>0.05)$ among the values of the other internal organs of turkeys fed the various dietary treatments. The values of all the internal organs did not follow any definite pattern with increase in level of replacement.

There was no significant difference $(\mathrm{P}>0.05)$ in the values of spleen of turkeys fed diets 1, 2, 3, 5, and 6. It implies that palm kernel meal can replace maize up to 100 percent and the immunity of the birds against disease guaranteed since spleen is the major source of lymphocytes and the storage site for white and red blood cells (Frandson,1981). The good performance of turkeys fed diet 4 could be due to their good health status which did not predispose the spleen to greater production of white blood cells which could be responsible for low spleen weight of the birds.

It is recommended that palm kernel meal can replace maize at 60 percent for good growth and carcass performance of local broiler turkeys.

\section{References}

Aduku, A.O. 1993. Tropical Feedstuff analysis. Table. Dept. of Animal Science, Faculty of Agriculture, Ahmadu Bellow University, Zaria Nigeria.

Ataga, D.O. 1984. The potentials of the oil palm industry in the Nigerian economy. A paper presented in a workshop: Theme: "Prospect of Oil
Palm Production in Nigeria" at Nigeria Institute of Oil Palm Research, Benin City, Nigeria in June, 1984.

Babatunde, G.M. Fetuga, B.L., Odumosu, O. and Oyenuga, V.A. 1975. Palm Kernel Meal as a major protein concentrate in the diets of pigs in the tropics J. Sci. Food Agric, 26: 127-1291.

Bains B.S. 1979. A manual of Poultry Disease. Published by F. Hoffmann LaRoche and co. Ltd. Company basle, Switzerland. Pp 133-161.

Duncan, D.B. 1955. Multiple Range and Multiple F. test. Biometrics 11:1-42.

Dung, N.N.X., Manh, L.H. and Uden, P. 2002. Tropical Fibre Sources for pigs digestibility digesta retention and estimation of fibre digestibility in vitro. Anim. Feed Sci. Tech. 102:109124.

Durunna, C.S. Udedibie, A.B.I. and Anyanwu, G.A. 2000. Combinations of maize/sorghum-based dried brewers grains, cocoyam corn and cassava tuber meals as substitute for maize in the diets of laying hens. Proc. of the $25^{\text {th }}$ annual Conf. of the Nigerian.Soc. For Anim. Prod. Pp 169-173 at Umudike: Theme: "Animal Production in the New Millennium: challenges and options".

Eruvbetine, D., Biobaku, W.O.., Sodimu, A.O. and Oguntona E.B. 1996. Manual of poultry farming for southwest Nigeria. Published by agricultural Media Resources and extension Centre AMREC, University of Agriculture, Abiokuta, Nigeria. Extension Manual Livestock Series No. 1 Pp 1-44.

Esonu, B.O. and Udedibie A.B.I. 1993. The Effect of Replacing Maize with Cassava Peel Meal on the performance of weaned rabbits. Nig. J. Anim. Prod. 20:81-83. 
Felix, A., Hill, R.A. and Diarra, B. 1990. In vitro and in vivo digestibility of soyabean straw treated with various alkalis. Brit. Soc. of Anim. Prod. 51:47-61.

Ferket, P.R. and Sell, J.L. 1980. Effect of Severity of early protein restriction on large turkey Toms. 2: Carcass characteristics. Poult. Sci. 68:687-697.

Fetuga, B.L., Babatunde, G.M. and Oyenuga, V.A. 1973. Protein quality of some Nigerian Feedstuffs. Chemical assay of nutrients and amino acid composition. J. Sci. Food Agric. 24, 1505-1514.

Fetuga, B.L., Babatunde, G.M. and Oyenuga, V.A. 1977a. The value of Palm kernel meal in finishing diets for pigs/The effect of varying the proportion of protein from blood meal and palm kernel meal on performance and carcass quality of finishing pigs. Journal of Agric. Sci. 88, 655-661.

Frandson, R.D. 1981. Anatomy and physiology of farm animals. $3^{\text {rd }}$ edn. Published by Bailliere Tindall, London. Pp 62-94.

Godin, V. J. and Splensley, P.C. 1972. Oil and Oil Seeds. Tp1 Crop and Product digests. Published by the Tropical Products Institute, Foreign and Common Wealth Office, London Pp 56-58.

Gurr, M.I. and Harwood, J.L. 1991. Lipid Biochemistry. $4^{\text {th }}$ edn. Published by Chapman and Hall, 2-6 boundary Row London SE/8HN. Pp 1-115.

Gupta, B.S., Johnson, D.E., Hinds, F.C., Minor, M.C. 1973. Forage Potential of Soybean straw. Agronomy J. 65: 538541.

Hutagahung, R.I. 1980. Availability of Feedstuff for Farm animals. Asso. Australian Animal Science Congress. Abstract No. 40, 15.
Jegede, J.O., Tegbe, T.S.B., Aduku, A. and Olorunju, S.A.S. 1994. The effect of feeding palm kernel meal on performance and carcass characteristics of pigs. Nig. J. Anim. Prod. 21 No 1 and 2 Pp 88-95.

Leeson, S. and summers, J.D. 1980. Production and Carcass Characteristics of the large white Turkey. Poult. Sci.29: 1237-1245.

McDonald, P., Edwards, R.A., Greenhalgh, J.F.D. and Morgan, C.A. 1995. Animal Nutrition. $5^{\text {th }}$ edn. Longman scientific and Technical England. Pp 21-237.

Nwokolo, E.N., Bragg, D.B. and Saben, H.S. 1977. A nutritive evaluation of palm kernel meal for use in poultry rations. Trop. Sci. 19, 147-154.

Obioha, F.C. 1992. A guide to poultry production. Acena, publication Enugu, Nigeria. Pp 85-124.

Ojewola, G.S., Abasiekong, S.F. and Nwachukwu, C.S. 2001. Methionine supplementation in the productive efficiency, Carcass characteristics and economics of growing indigenous turkey Trop. J. of Anim. Sci. 42:161170.

Ojewola, G.S., Oguike, M.A., Akomas, S.C., Likita, T., Onyiro, O.M. and Wokocha, C. 2003. Comparison of the Supplemental effects of Roxazyme. Genzyme in palm kernel meal and brewers dried grain based diets fed to male turkey poults. Nig.Agric. J. 34: 116-124.

Olomu, J.M. 1995. Monogastric Animal Nutrition $1^{\text {st }}$ edn. A. JACHAM publication, Benin City, Nigeria. Pp67163.

Onwudike, O.C. 1986a. Palm Kernel as feed for poultry 1: Compository of Palm Kernel and availability of its amino acids to chicks Anim. Feed Sci. 
Tech. 16, 179-186.

Onwudike, O.C. 1986b. Palm Kernel as feed for poultry 2: Diets containing palm kernel meal for starter and grower pullers. Anim. Feed Sci. Tech. 16, 187194.

Oyenuga, V.A. 1968. Nigeria's Foods and Feeding stuffs. $3^{\text {rd }}$ edn. Ibadan University Press. University of Ibadan, Nigeria. Pp 70-79.

Sell, J.L., Hasiak, R.J. and Owings, W.J. 1985. Independent effects of dietary, metabolisable energy and protein concentrations on performance and carcass characteristics of Tom Turkeys. Poult. Sci. 64:1527-1535

Sell, J.L., Ferket, P.R., Angel, C.R. and Sheeideler, S.E. 1989. Performance of Carcass characteristics of turkey toms as influenced by dietary protein and metabolisable energy. Nutr. Rep. Int. 40 3; 97-992.

Steel, R.G.D. and Torrie, J.N 1980. Principles and Procedures of Statistics. McGraw-Hill Book Co. New York. Pp 65-86.

Summers, J.A., Leeson, S., Bellford, M. and Spratt, D. 1985. Influence of dietary protein and energy on performance and carcass composition of heavy turkeys. Poult. Sci. J. 64:1921-1933.

Summers, J.D. and Spratt 1990. Weight gain, carcass yield and composition of large white male turkeys reared to 28 weeks of age on growing and finishing diets with varying levels of dietary protein. Poult. Sci.69: 584-591.

Temperton, H., and Dudley, F.J. 1940. Palm Kernel and earth nut meals in the ration of laying pullets. Harper Adams. Utility Poultry J. 25: 285-287.

Tewe, 0.O., Akinsoyinu, A.O., Ogisi, E.M. 1982. Grain replacement value of cassava and sweet potatoes in ration of lambs 2; Energy and Protein Utilization. Nig. J. Anim. Prod. 92, 94101.

Ugwuene, M.C., Onwudike, O.C., Abasiekong, S.F. and Nnadiekwe, C.M. 2005. Effect of replacing Maize with full-fat palm kernel in broiler diets. Proc. of the $30^{\text {th }}$ annual Conf. of the Nig. Soc. for Amin. Prod. Univ. of Nig. Nsukka. Pp 179-182.

Ukachukwu，S.N., Ojewola, G.S. Abasiekong, S.F. and Uzuegbu, C.P. 2003. Biologic and Economic effects of different Agro-Industrial byproducts in turkey poult diets. Nig. Agric. J. 34: 138-142.

Yerong, S.W. 1980. The Nutritive value of Palm Oil by-products for poultry. Proc. Abstr. First Asia-Australia Animal Science Congress Abstr. No 45, 17. 